\title{
Surfaces and Interfaces for Renewable Energy
}

\author{
Francisco Manzano-Agugliaro ${ }^{1, *(1)}$ and Aránzazu Fernández-García ${ }^{2}$ \\ 1 Department of Engineering, University of Almeria, ceiA3, 04120 Almeria, Spain \\ 2 CIEMAT-Plataforma Solar de Almería, Ctra. Senés, 04200 Tabernas, Spain; afernandez@psa.es \\ * Correspondence: fmanzano@ual.es; Tel.: +34-950-015791; Fax: +34-950-015491
}

Received: 5 December 2019; Accepted: 6 December 2019; Published: 9 December 2019

check for updates

\begin{abstract}
Energy is a growing need in today's world. Citizens and governments are increasingly aware of the sustainable use that must be made of natural resources and the great negative impact on the environment produced by conventional energies. Therefore, developments in energy systems based on renewable energies must be carried out in the very near future. To ensure their sustainability, they must be made of durable materials, and for this, the study of coatings is extremely important. This is also vital in systems based on solar energy, where the optical properties of the materials must be preserved as long as possible, and to this must be added the fact that they tend to be installed in very aggressive environments from the point of view of corrosion. Therefore, this special issue aims to contribute to the development of this challenge.
\end{abstract}

Keywords: solar energy; coatings; thin film; reflector; light trapping; concentrating solar thermal energy; reflectance corrosion

\section{Introduction}

The worldwide demand for electricity will grow to $50 \%$ in the next 20 years, mainly due to the increase in the world population, the generalization of electric vehicles as a form of transport and the boom in the battery market. However, this huge increase will be covered almost completely by renewable energy sources. The durability of renewable energy systems depends to a large extent on their surfaces. The improvement of coatings is one of the great challenges of the engineering and material science applied to these systems. This Special Issue will focus on the developments in this particular domain.

This Special Issue includes theoretical or practical issues of the following topics of interest, but are not limited to:

- Antireflective coatings;

- Antisoiling coatings;

- Corrosion resistance coatings;

- Increased optical properties (reflectance, absorptance, transmittance, and emittance);

- Surface treatment;

- Solar cells;

- Scanning electron microscopy;

- X-ray diffraction;

- Thin films;

- Polymers;

- Plastic coatings;

- Corrosion;

- Nanoparticles and nanotechnology; 
- Titanium dioxide;

- Carbon nanotubes;

- Aluminum coatings;

- Paints;

- Composite materials;

- Environmental impact;

- Lifetime prediction;

- Accelerated aging methods; and

- Optical measurement techniques.

\section{Statistics of the Special Issue}

The authors' geographical distribution by country for the published papers is shown in Table 1, where it is possible to observe 27 authors from Spain and Germany.

Table 1. Geographic distribution by the country of author.

\begin{tabular}{cc}
\hline Country & Number of Authors \\
\hline Spain & 16 \\
Germany & 11 \\
\hline Total & 27 \\
\hline
\end{tabular}

\section{Authors of this Special Issue}

The authors of this special issue and their main affiliations are summarized in Table 2, where there are four authors on average per manuscript.

Table 2. Affiliations and bibliometric indicators for the authors.

\begin{tabular}{cccc}
\hline Author & Main Affiliation & Country & Reference \\
\hline Francisco Buendía-Martínez & CIEMAT-Plataforma Solar de Almería & Spain & {$[1,2]$} \\
Aránzazu Fernández-García & CIEMAT-Plataforma Solar de Almería & Spain & {$[1,2]$} \\
Florian Sutter & German Aerospace Center (DLR) & Germany & {$[1,2]$} \\
Loreto Valenzuela & CIEMAT-Plataforma Solar de Almería & Spain & {$[1]$} \\
Alejandro García-Segura & CIEMAT-Plataforma Solar de Almería & Spain & {$[1]$} \\
Johannes Wette & German Aerospace Center (DLR) & Germany & {$[2]$} \\
David Argüelles-Arízcun & CIEMAT-Plataforma Solar de Almería & Spain & {$[2]$} \\
Itziar Azpitarte & IK4-Tekniker & Spain & {$[2]$} \\
Gema Pérez & Rioglass Solar S.A. & Spain & {$[2]$} \\
Ceyhun Oskay & DECHEMA-Forschungsinstitut & Germany & {$[3]$} \\
Tobias M. Meißner & DECHEMA-Forschungsinstitut & Germany & {$[3]$} \\
Carmen Dobler & DECHEMA-Forschungsinstitut & Germany & {$[3]$} \\
Benjamin Grégoire & DECHEMA-Forschungsinstitut & Germany & {$[3]$} \\
Mathias C. Galetz & DECHEMA-Forschungsinstitut & Germany & {$[3]$} \\
Karmele Vidal & IK4-Tekniker & Spain & {$[4]$} \\
Estíbaliz Gómez & IK4-Tekniker & Spain & {$[4]$} \\
Amaia Martínez Goitandia & IK4-Tekniker & Spain & {$[4]$} \\
Adrián Angulo-Ibáñez & IK4-Tekniker & Spain & {$[4]$} \\
Estíbaliz Aranzabe & IK4-Tekniker & Spain & {$[4]$} \\
Sophie Gledhill & Fraunhofer Institute for Solar Energy Systems & Germany & {$[5]$} \\
Kevin Steyer & Fraunhofer Institute for Solar Energy Systems & Germany & {$[5]$} \\
Charlotte Weiss & Fraunhofer Institute for Solar Energy Systems & Germany & {$[5]$} \\
Christina Hildebrandt & Fraunhofer Institute for Solar Energy Systems & Germany & {$[5]$} \\
Nuria Novas & University of Almeria & Spain & {$[6]$} \\
Alfredo Alcayde & University of Almeria & Spain & {$[6]$} \\
Dalia El Khaled & University of Almeria & Spain & {$[6]$} \\
Francisco Manzano-Agugliaro & University of Almeria & Spain & {$[6]$} \\
\hline
\end{tabular}




\section{Brief Overview of the Contributions to This Special Issue}

If a brief representation of all the keywords of the articles of the Special Issue is made by means of a cloud of words, Figure 1 is obtained. Here, it is observed that the predominant keywords are Solar, Coating, Film, and Thin.

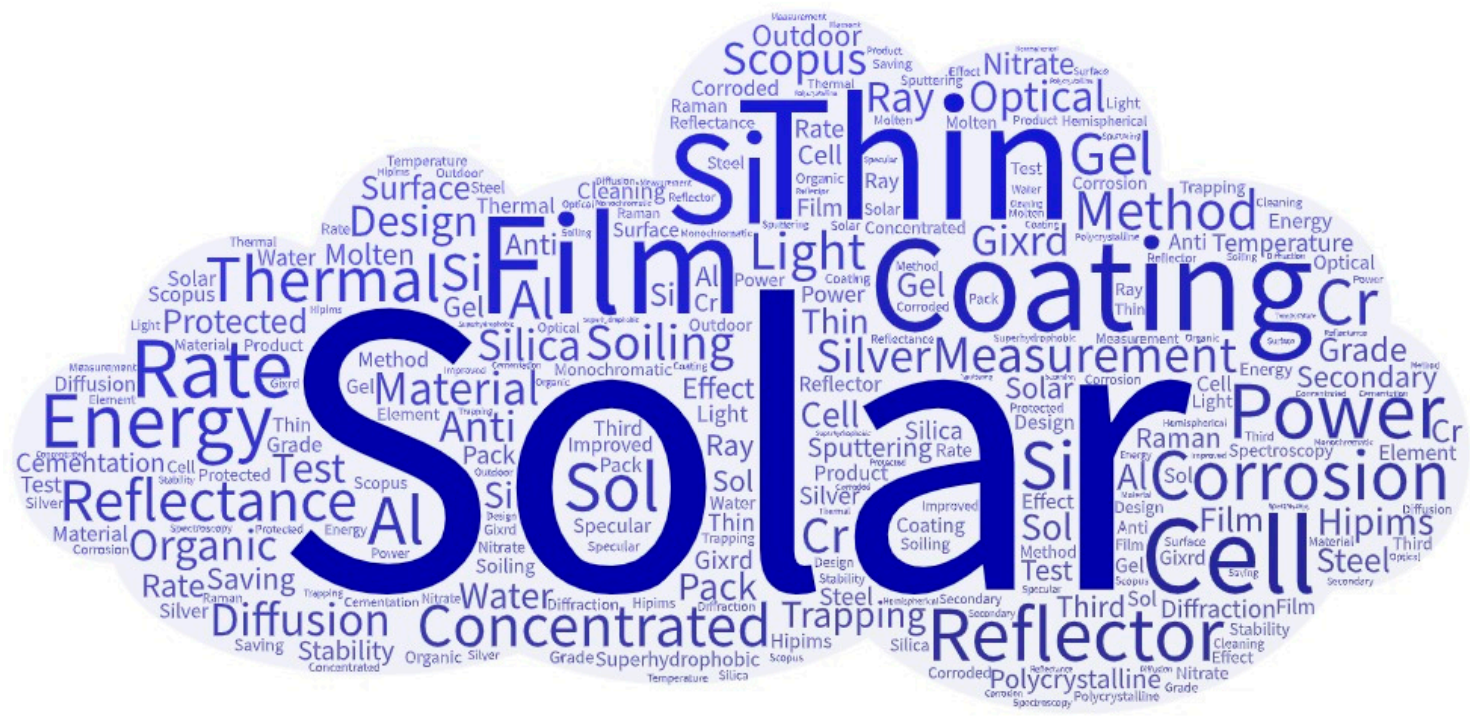

Figure 1. Cloudword of all the keywords.

Author Contributions: All authors contributed equally to this work.

Conflicts of Interest: The authors declare no conflict of interest.

\section{References}

1. Buendía-Martínez, F.; Fernández-García, A.; Sutter, F.; Valenzuela, L.; García-Segura, A. Advanced Analysis of Corroded Solar Reflectors. Coatings 2019, 9, 749. [CrossRef]

2. Wette, J.; Fernández-García, A.; Sutter, F.; Buendía-Martínez, F.; Argüelles-Arízcun, D.; Azpitarte, I.; Pérez, G. Water Saving in CSP Plants by a Novel Hydrophilic Anti-Soiling Coating for Solar Reflectors. Coatings 2019, 9, 739. [CrossRef]

3. Oskay, C.; Meißner, T.M.; Dobler, C.; Grégoire, B.; Galetz, M.C. Scale Formation and Degradation of Diffusion Coatings Deposited on 9\% Cr Steel in Molten Solar Salt. Coatings 2019, 9, 687. [CrossRef]

4. Vidal, K.; Gómez, E.; Goitandia, A.M.; Angulo-Ibáñez, A.; Aranzabe, E. The Synthesis of a Superhydrophobic and Thermal Stable Silica Coating via Sol-Gel Process. Coatings 2019, 9, 627. [CrossRef]

5. Gledhill, S.; Steyer, K.; Weiss, C.; Hildebrandt, C. HiPIMS and DC Magnetron Sputter-Coated Silver Films for High-Temperature Durable Reflectors. Coatings 2019, 9, 593. [CrossRef]

6. Novas, N.; Alcayde, A.; El Khaled, D.; Manzano-Agugliaro, F. Coatings in Photovoltaic Solar Energy Worldwide Research. Coatings 2019, 9, 797. [CrossRef]

(C) 2019 by the authors. Licensee MDPI, Basel, Switzerland. This article is an open access article distributed under the terms and conditions of the Creative Commons Attribution (CC BY) license (http://creativecommons.org/licenses/by/4.0/). 